

\title{
Diathesis and Middle Voice in the Syriac Ancient Grammatical Tradition: The Translations and Adaptations of the Téchne Grammatiké and the Arabic Model \\ Margherita Farina
}

\section{To cite this version:}

Margherita Farina. Diathesis and Middle Voice in the Syriac Ancient Grammatical Tradition: The Translations and Adaptations of the Téchne Grammatiké and the Arabic Model. Aramaic Studies, 2008, 6 (2), pp.175-193. 10.1163/147783508X393039 . hal-02106697

\section{HAL Id: hal-02106697 https://hal.science/hal-02106697}

Submitted on 30 Apr 2019

HAL is a multi-disciplinary open access archive for the deposit and dissemination of scientific research documents, whether they are published or not. The documents may come from teaching and research institutions in France or abroad, or from public or private research centers.
L'archive ouverte pluridisciplinaire HAL, est destinée au dépôt et à la diffusion de documents scientifiques de niveau recherche, publiés ou non, émanant des établissements d'enseignement et de recherche français ou étrangers, des laboratoires publics ou privés. 


\title{
Diathesis and Middle Voice in the Syriac Ancient Grammatical Tradition: The Translations and Adaptations of the Téchne Grammatiké and the Arabic Model
}

\author{
Margherita Farina \\ Laboratorio di Linguistica, Scuola Normale Superiore di Pisa
}

\begin{abstract}
A number of ancient Syriac grammars are analysed, as far as the passages related to diathesis are concerned. It appears that the concept and the definition of diathesis vary diachronically, but also according to the theoretical framework chosen by the authors. The influence of different Greek and Arabic models (and of their interactions) causes variation in the perspective under which diathesis is conceived and described. Particular attention is devoted to the middle diathesis, which is attributed to Syriac exclusively in the translation of the Téchne Grammatiké, made by Huzaya in the VI century. The comparison of the Greek original with the Syriac translation may also shed some light on the concept of middle diathesis, as meant in the Téchne.
\end{abstract}

\section{Keywords}

Diathesis, Syriac grammar, Téchne

Vis et felicitas inventionis, qua gaudet grammaticae scriptor, posita est in methodo qua linguae proprietates suo modo percipit, disponit, describit

Merx $^{1}$

1) A. Merx, 'Historia artis grammaticae apud Syros', Abhandlungen für die Kunde des Morgenlandes 9 (1889), p. 231. 


\section{The Translation of the Téchne by Huzaya}

\section{a. Diathesis of the Verb}

In the VI century the Syriac grammarian (maqryaina 'teacher of reading') Huzaya wrote a translation ${ }^{2}$ of the Téchne Grammatiké, controversially attributed to Dionysius Thrax (grammarian and philologist of the II cent. b.C.). ${ }^{3}$

The main source of such a translation is the text given in the appendix of the history of Syriac grammar by Merx. ${ }^{4}$

Recently Contini ${ }^{5}$ has proposed an interesting analysis of some passages of Huzaya's text, that will be discussed here.

Not all of the Greek original has been rendered into Syriac by Huzaya: the sections on orthography and phonology, for example, are missing. According to Contini the omission of some parts can be due to the difficulty of applying to the Syriac language categories that are conceived specifically for the description of Greek:

... l'omissione dei capp. 2-Io (che trattano di questioni ortografiche, fonologiche e prosodiche) si spiega facilmente con la sensibile divergenza fonologica tra il greco e l'aramaico-oltreché con l'esistenza di una tradizione siriaca indigena di notazione ortoepica che in parte suppliva alla mancanza di sistemi organici di vocalizzazione.. .6

The section on diathesis has been nevertheless translated by Huzaya, who uses the following terminology: ${ }^{7}$

2) Or, in Contini's words, an adaptation, cf. R. Contini, 'Considerazioni interlinguistiche sull'adattamento siriaco della Téchne Grammatiké di Dionisio Trace', in R.B. Finazzi and A. Valvo, La diffusione dell'eredità classica nell'età tardoantica e medievale-il romanzo di Alessandro e altri scritti (Alessandria: Edizioni dell'Orso, I998), pp. 95-III.

3) The attribution of this work to Dionysius has been a matter of debate from antiquity until nowadays. Cf. the three important contributions by V. Di Benedetto: 'Dionisio Trace e la Techne a lui attribuita', Annali della Scuola Normale Superiore di Pisa. Lettere, Storia e Filosofia. Serie 2, 27 (1958), pp. I69-2Io, idem, 'Dionisio Trace e la Techne a lui attribuita', Annali della Scuola Normale Superiore di Pisa. Lettere, Storia e Filosofia. Serie 2, 28 (1959), pp. 87-II8 and idem, 'La Techne spuria', Annali della Scuola Normale Superiore di Pisa. Classe di Lettere e Filosofia. Serie 3, 3 (1973), pp. 797-8I4. For an overview of the main current hypothesis, cf. also V. Law and I. Sluiter (eds.) Dionysius Thrax and the Techne Grammatike (Münster: Nodus, 1995).

4) A. Merx, 'Historia artis grammaticae'.

5) R. Contini, 'Considerazioni interlinguistiche'.

6) R. Contini, 'Considerazioni interlinguistiche', p. Ioo.

7) Translations according to J. Payne Smith, A compendious Syriac Dictionary (Oxford: 











'to be in the middle' a good literal rendering. This term, according to the Thesaurus Syriacus is used:

a. in the sense of Latin mediatio, interventio, for example in juridical lexicon, or in idiomatic expressions meaning 'by means of', also in composition with the preposition $b$-;

b. less frequently in the sense of Latin medietas, media pars.

A number of quotations in the Thesaurus Syriacus ${ }^{8}$ are from grammatical texts or lexica. It is interesting to notice that in none of them mes'ay $\hat{u} t a ̊ a p p e a r s$ to have a meaning analogous to 'middle voice' or even related to the area of verbal diathesis. In the grammar of Amir, ${ }^{9}$ for example, it is used in the second sense, in the compound meśayut syåma lit. 'position of the middle' to indicate (almost literally) interjection. ${ }^{10}$ Finally, in the lexica of Bar Bahlul and Bar Ali, the term is rendered with various terms from the Arabic root وسط (wst) 'middle, midst'.

As already noticed by Talmon: ${ }^{11}$ 'Many of the terms used in his translation have not been taken over by later grammarians, such as the names of the nominal cases, the term mṣalyutâ ${ }^{12}$ [sic!] (mesótes) "middle voice of the verb"...'.

According to what follows in the Greek original, the three categories are briefly exemplified. The whole passage is thus:



Clarendon Press, 1903) and R. Payne Smith, Thesaurus Syriacus (Oxford: Clarendon Press, I879).

8) Thesaurus Syriacus, p. 2194.

9) Georgius Michael Amira, Grammatica Syriaca sive chaldaica (Rome: Jacobus Luna, 1596).

10) According to J. Payne Smith, A compendious Syriac Dictionary, p. 375, the same compound can also indicate a preposition.

11) R. Talmon, 'Foreign influence in the Syriac grammatical tradition', in S. Auroux,

E.F.K. Koerner, H.J. Niederehe and C.H.M. Versteegh, History of the language sciences (Berlin and New York: Mouton de Gruyter, 2000), pp. 337-34I, esp. p. 337.

12) The consonantal misreading msalyutâ for mes'ayûtå has to be explained as a lapsus. 




Diatheseis (lit. qyåmê, 'positions') are three: the active (ma'bdånutå), the passive ( hašå) and the middle one (meș'ayûtå). The active is like 'I hit' (maḥ̂ 'nå), 'I do' ('åbed 'nå), 'I write' (kateb 'nå). The passive is like 'I am hit' (metmhêe 'nå), 'I am done' (met'bed 'nå), 'I am written' (metkteb 'nå). The middle is that which is 'posed' [〉 expressed, conveyed] sometimes by the active and sometimes by the passive, like 'I travelled' (rdêt), 'I went' (helket), 'I sat' (yetbet), 'I ran' (rehtet), 'I passed' ('ebret).

The corresponding original Greek text is the following:







The passage has been shortly analysed by Contini, who notes:

La definizione del medio è tradotta in modo goffo, ma è inequivocabilmente vólta a darne un'accezione esclusivamente semantica ("è espresso da" vs. $\pi \alpha \varrho \iota \tau \tilde{\alpha} \sigma \alpha$ "che esprime" dell'originale), come si conviene a una categoria verbale che non ha rilevanza morfologica in siriaco: e gli esempi proposti scollegati come sono da quelli della Vorlage, si giustificano solo nella loro indubbia compatibilità con una "semantica media". ${ }^{15}$

[...] In vari casi (composizione nominale e preposizionale, diatesi) si è mostrato come l'adattamento siriaco, pur non limpido nell'espressione, di fatto nasconda intuizioni rispettabili sulla morfosintassi della sua lingua materna ${ }^{16}$

The scholar highlights here the most important feature of this passage: the middle is not indicated here as a morphological category that conveys a number of meanings (as in the Greek original), but as a semantic category that can be expressed either by the active or by the passive. Instead of the Greek $\pi \alpha \varrho$ ot $\tilde{\alpha} \sigma \alpha$ 'expressing', Huzaya uses the etpa" $a l$ participle metqayyåmå 'posed, expressed'. A few further remarks need to be added.

13) A. Merx, 'Historia artis grammaticae', p. 6o*.

14) G. Uhlig, 'Dionysii Thracis ars grammatica: qualem exemplaria vetustissima exhibent subscriptis discrepantiis et testimoniis quae in codicibus recentioribus scholiis erotematis apud alios scriptores interpretem armenium reperiuntur...', in Grammatici graeci: recogniti et apparatu critico instructi (Leipzig: Teubner, 1867-1910, repr. Hildesheim: Olms, 1965), pars prima, I, p. 46.

15) R. Contini, 'Considerazioni interlinguistiche', p. Io6.

16) R. Contini, 'Considerazioni interlinguistiche', p. Io9. 
As noticed by Contini, the examples that follow the definitions are not mere translations of the Greek ones. Nevertheless, the distribution of the Syriac examples, with respect to the Greek ones, is even more complex: Huzaya picks


and the corresponding 'passive' et-forms. The equivalents of such lexemes, in the Greek original, belong to the series illustrating the 'middle voice', and have been moved to the active and passive categories. The 'middle', instead, has been illustrated through a number of verbs lexically independent from the Greek ones. All of them are motion verbs.

More important, although middle can be considered, and is considered by modern scholars, a specific morphological category in ancient Greek, the examples given in the Téchne Grammatiké are not homogeneous with respect to morphology, being in part radical perfects, with active endings and intransitive


with 'middle' endings ('̇ло



17) In the light of my further observations, I think that the underlying Greek verb is here $\pi \dot{\varepsilon} \tau \gamma \gamma \alpha$, rather than $\tau \dot{\pi} \tau \tau \omega$.


intransitively (with medio-passive value).

19) Also these two verbs at the middle aorist can have both passive and middle-reflexive meaning ('I made for my self, I wrote myself').

20) A fact that could be related to the developments of late and modern Greek. Cf. for example the thorough description in A.T. Robertson, A Grammar of the Greek of the New Testament in the Light of Historical Research (Nashville, Tennessee: Broadman Press, 1934). More specifically Ch. VIII, par. VI, p. 334 (e) The Passive Supplanting the Middle: 'In the modern Greek the middle has no distinctive form save $\lambda \dot{v} \sigma o v$ (cf. $\lambda \tilde{v} \sigma \alpha \iota)$ and this is used as passive imperative second singular. Elsewhere in the aorist and future the passive forms have driven out the middle. These passive forms are, however, used sometimes in the middle sense, as was true of $\dot{\alpha} \pi \dot{\varepsilon} x \varrho \iota \vartheta \varepsilon$, for instance, in the N.T. the passive forms maintain the field in modern Greek and appropriate the meaning of the middle. We see this tendency at work in the N.T. and the koine generally. Since the passive used the middle forms in all other tenses, it was natural that in these two [namely, in the aorist and future] there should come uniformity also. The result of this struggle between the middle and passive in the aorist and future was an increasing number of passive forms without the distinctive passive idea'. If this connection is correct, that could be an argument in favour of a later dating at least of this section of the Téchne. From a different perspective, one could also interpret it as the emergence of a feature of the spoken language (therefore not necessarily late), as opposed to the classical and literary use (this second hypothesis was suggested to me by Prof. R. Lazzeroni, from Pisa University). 
The middle diathesis is described as a category of verbs that 'sometimes'


to illustrate such a definition, as just noticed, differ from the morphological point of view mainly because two of them have active endings and two of them middle endings. Nevertheless, two features unite all of them:

- they can be used either intransitively, with what we would call medio-passive or medio-reflexive meaning or transitively (

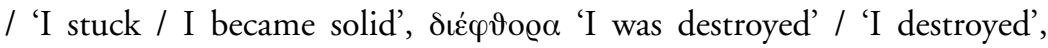

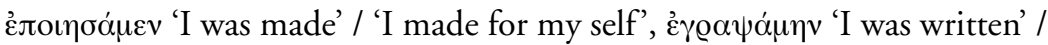
'I wrote myself'); ${ }^{21}$

- they may show a contradiction between morphology and meaning (the first two active morphology and passive meaning, the second two passive morphology ${ }^{22}$ and active meaning).

These two characteristic of the examples given in the Téchne, caused in later commentators (at least) two different interpretations of the passage.

According to the first one, the passage of the Téchne says that there can be a contradiction between the morphology and the semantic value of the verb. Thus, in Sophronius the following remark, clearly connected with the passage of the Téchne, is found:

\footnotetext{
$\Delta$ เ









The second interpretation is that the same morphological elements may convey different meanings. This interpretation may be found in the Etymologicum







21) Cf. H.G. Liddell and R. Scott, A Greek-English Lexicon (Oxford: Oxford University Press, 1978).

22) According to the definition of passive given in the Téchne in the same passage.

23) Grammatici graeci, pars quarta, 4.2, p. 4II.

24) (Kallierges 754,26). Source: Thesaurus Linguae Graecae (TLG): A Digital Library of Greek




Not all of these observations may be of immediate relevance for the understanding of the Syriac text. What they certainly highlight is that, even though the theoretical framework in the Greek text presupposes a morphological category of 'middle' able to express certain meanings, the examples that follow contradict such a framework and are along the same line as the Syriac ones.

From all the previous observations three main conclusions can be drawn, as regards the conception that Huzaya had of 'middle diathesis':

I. it as a category that could be applied to Syriac verb;

2. it can be expressed sometimes by active and sometimes by passive forms;

3 . it is related to motion verbs.

Observing the motion verbs used to exemplify middle diathesis, it is possible to notice that:

- they are all quoted at the active (basic) stem. No et- stem is used to exemplify the 'middle'. Moreover, for the verbs listed, the et-stems are either unattested or marginal, with specific secondary meaning, with the exception of the etstems of $\hat{t} t e b$, that are nevertheless quite ambiguous with respect to diathesis;

- two of them belong to an 'intransitive vowel pattern'; $; 5$

- the qtîl participle has active value for $r h e t$, while for $r d a ̊ a n d ~ ' b a r$ has passive value but only for peripheral meanings of the verbs (respectively eruditus and superductus). It is not attested for hlak and $\hat{\imath} t e b$;

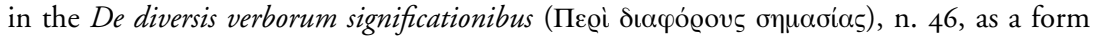
that can have two different meanings, in terms of diathesis:



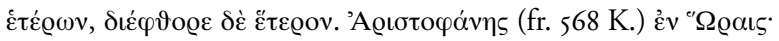

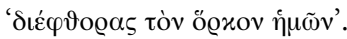

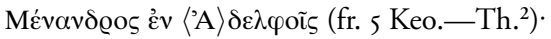

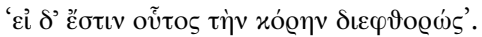

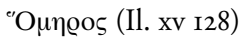

'

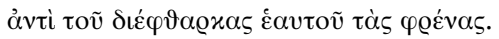

Source: $T L G$.

The interpretation of this passage of the Téchne, that has been given here, is also supported by the observations made by J. Lallot, La grammaire de Denys le Thrace (Paris: CNRS, 1989), pp. 166-167.

25) Cf. T. Muraoka, Classical Syriac. A Grammar with a Chrestomathy (second, revised edition; Wiesbaden: Harrassowitz, 2005), \$55-56. 
- from the semantic point of view, all the verbs quoted by Huzaya belong to the category of unaccusatives. ${ }^{26}$

\section{b. Diathesis of the Noun}

The passage analysed so far is not the only one in which diathesis is mentioned in Huzaya's grammar. Following the Greek model, in fact, the translator has indicated it also as a feature of the noun:

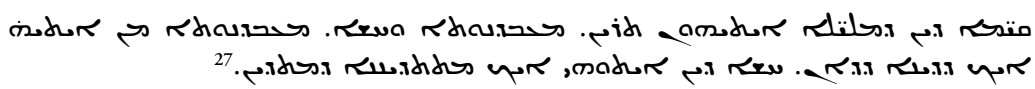

Diatheseis of the word are two: active (ma bdånutå) and passive (hăåa). Active is like 'judge' (dayånå), that judges (da'en, active $p^{\prime}$ al participle), while passive is like 'judged' (mettdînånå verbal noun), that is judged (metdîn, etp'el. participle).

Which is clearly a literal translation of the passage in the Téchne (stigmatized by the following tradition):

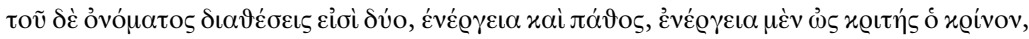

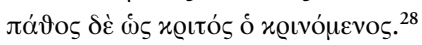

As will be shown further on in this work, this remark has a tradition throughout the Syriac grammar, and will be included and differently developed among others by Bar Šakku and Bar Hebraeus. Merx ${ }^{29}$ had already individuated the

26) For a definition of this linguistic category see, among others, D.M. Perlmutter, 'Impersonal Passives and the Unaccusativity Hypothesis', in Proceedings of the Fourth Annual Meeting of the Berkeley Linguistic Society, (Berkeley: Berkeley Linguistic Society, University of California, 1978), pp. 157-189, and R.D. Van Valin, 'Semantic Parameters of Split Intransitivity', Language 66 (1990), pp. 22I-260.

27) A. Merx, 'Historia artis grammaticae', p. 59*.

28) G. Uhlig, Dionysii Thracis ars grammatica, p. 46. On which the Scholiast comments:

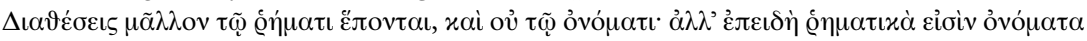

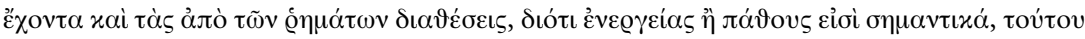

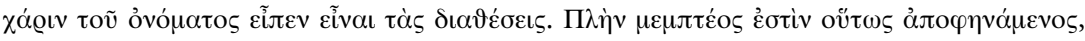

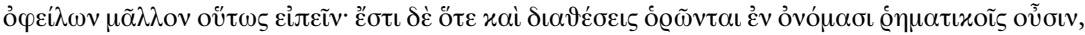

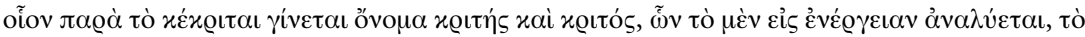

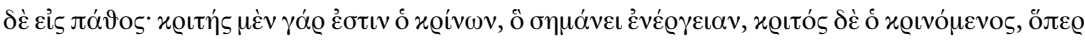
$\pi \alpha ́ \vartheta 0 \varsigma$ $\delta \eta \lambda \circ \tilde{\imath}$ (cf. A. Hilgard, Scholia in Dionysii Thracis artem grammaticam, in Grammatici graeci, pars prima, 3, p. 70).

29) A. Merx, 'Historia artis grammaticae', p. 240. 
Greek text as the possible source for Bar Hebraeus, but without any reference to Huzaya's translation.

\section{Diathesis in the Grammar of Bar Zu'bî}

Several centuries after the translation of Huzaya, in the twelfth and thirteenth centuries, other grammars of Syriac are found, that follow the Greek model of the Téchne. Nevertheless such works are not translations anymore, but in various manners their authors modify their structure and terminology, according to the features of the Syriac language.

The philosophical and grammatical reflection has progressed, and the Arabic cultural influence has given new impulse to the linguistic thought, even though without directly shaping all the grammars of Syriac. As will be shown in next paragraph, to the twelfth century dates the first attempt of application of the categories elaborated in the Arabic environment ${ }^{30}$ to the Syriac language.

Nevertheless, the imprint of the Téchne is still predominant in many important works of this period.

The grammar of Bar Zu'bî (beginning of the thirteenth century), recently studied and partially published by Georges Bohas, ${ }^{31}$ is also inserted along this line of the tradition.

From the account given by Bohas it appears that Bar Zu'bî mentions diathesis as one of the 'accidents' or types of affixes of the verb. ${ }^{32}$

30) Of course, Arabic linguistics have also been strongly based on a Greek model. But the Aristotelian conception has prevailed on the grammatical approach of the Téchne. A clear and elegant (although rather rigid) sketch of the relation between Arabic and Greek linguistics, also with respect to Syriac tradition, is found in A. Merx, 'Historia artis grammaticae', pp. 137-I57 and passim. On the relationship between Greek and Arabic linguistic thought and grammatical tradition, cf. the capital work by C.H.M. Versteegh, Greek elements in Arabic linguistic tradition (Leiden: Brill, 1977). Merx' reconstruction has been criticized (sometimes maybe too eagerly) by A. Elamrani-Jamal, Logique aristotélicienne et grammaire arabe (Paris: Vrin, 1983). Through an overview of the classic Arabic philosophical sources, the author shows how the idea of a direct filiation of Arabic linguistics from Aristotelian logics is, in many respects, problematic and superficial.

31) Cf. among others, G. Bohas, 'Les accidents du verbe dans la grammaire de Bar Zu'bî ou: une adaptation de la Technê', Langues et littératures du monde arabe 4 (2003), pp. 54-86. 32) naqîpwåtå. The term means literally 'affixes, adjuncts'. Nevertheless this translation appears inexact with respect to modern linguistic terminology, therefore I have opted for the unelegant phrase 'types of affixes', which at least describes appropriately the categories listed in the subsequent lines. For a discussion of the problem cf. G. Bohas, 'Les accidents du verbe', p. 56, where the term 'accidents' is chosen, in line with Brockelmann. Personally 


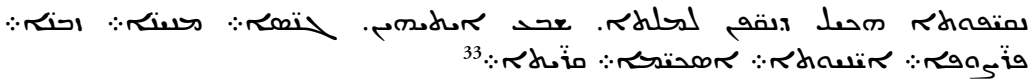

The types of affixes (naqîpwåtå) that attach to the verb are seven: genders, numbers, tenses, persons, diatheseis, schemes [Gr. schêma, form], modes.

From this passage it is already possible to notice a first difference from Huzaya's text, as regards diathesis: the term is rendered here by rhow (aynaiy $\hat{u} t a ̊ a)^{34}$ 'quality', whereas Huzaya used a more literal translation of the Greek term diathesis (Greek root *the' 'put, set').

Furthermore, when treating specifically of diathesis, Bar Zu'bî indicates for

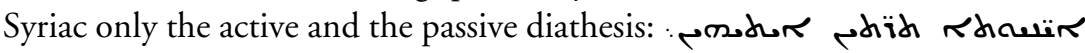
Khrovon Rhouras. "diatheseis (aynaywåtå) are two: active (m'abdånûtà) and passive (hašûstå)'. No reference to a 'middle' diathesis is made. As observed by Bohas (p. 67): 'pour lui [scil. Bar Zu'bî], il n'y a pas à parler en syriaque de diathèse moyenne'.

Examples of the two diatheseis follow:

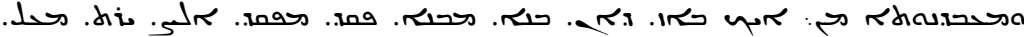

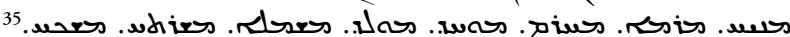

And the active is like: 'he spoils', ${ }^{36}$ 'he judges', 'he builds' [basic stem of bny], 'he restores' [intensive stem of $b n y$ ], 'he orders' [basic of $p q d$ ], 'he commands' [intensive of $p q d$ ], 'he presses', 'he inherits', 'to bring in' [causative stem of 'l], 'he relieves' [causative stem of $n w h$ ], 'he throws, puts down' [causative stem of $\mathrm{rm}^{\prime}$ '], 'he declares sacer' [causative stem of hrm, basic stem unattested], 'he delays' [causative stem of unattested base $w h d$ ] ], 'he generates' [causative of $w l d]$, 'he accomplishes' [ $\check{s}$ stem of $m l$ '], 'he makes abundant' [ $\check{s}$ stem of $r t h]$ ], 'he finds'.

One immediately notices that the examples given by Bar $\mathrm{Zu}$ 'bî are much more numerous than those given by Huzaya (which, as we have seen, are an adaptation of the Greek ones), and completely independent semantically from the Greek Téchne. Moreover, of the I7 verbs listed, II are derived stem, with intensive or causative value.

I am not sure that such an abstraction is meant in the Syriac text, that in my opinion refers rather to the real 'bricks' that can be added to the verb to build the various forms.

33) G. Bohas, 'Les accidents du verbe', p. 56.

34) From aynå 'which?'.

35) G. Bohas, 'Les accidents du verbe', p. 66.

36) Literally all the examples are present participles. The stem is the basic one, when not otherwise indicated. 
As regards the passive, the verbs listed are corresponding et-forms of the active verbs listed above ${ }^{37}$ plus other $e t$ - forms from different roots (at least according to the text presented by Bohas):

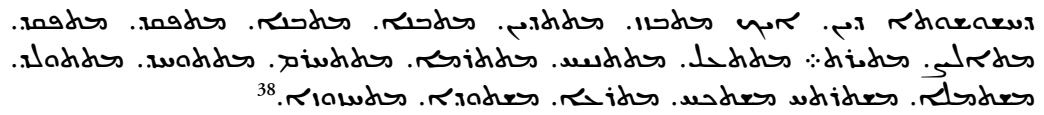

The following three verbs are added, with respect to the list of active ones: 'he is accepted / he thinks', 'he promises', 'he distinguishes himself'. ${ }^{39}$

What is interesting, in this list, is that not all of the et-forms are really or entirely passive in meaning, and especially the ones without an active counterpart appear to be active or middle: mettdîn 'he is judged', but also 'he judges'; metîret 'he is made to inherit, he is made the heir'; mettnîh 'he rests, refreshes himself'; mestamlê 'he becomes perfect, fulfilled'; metra' $\hat{e}$ 'he is accepted / he thinks'; mestawdê 'he promises'; methazhzề 'he distinguishes himself'.

What seems to be relevant for Bar $\mathrm{Zu}$ 'bî, in these forms, is that they are the morphological et-counterpart of the 'basic' ones listed above, more than their specific meaning.

Diathesis, therefore, does not seem to be here described properly as a semantic feature. It is generically considered as one of the 'affixes' of the verb, even more than on of its 'accidents' (cf. n. 32).

\section{The Arabic Model and Elias of Tirhan}

The first to describe the Syriac language according to the Arabic theories ${ }^{40}$ and techniques is Elias of Tirhan ( $\dagger$ IO49). His grammar is not a systematic description like the ones mentioned so far, and is conceived as a series of answers

37) Therefore, when two forms are given for the same root, two corresponding $e$ - derivates are found.

38) G. Bohas, 'Les accidents du verbe', p. 66.

39) On which Bohas remarks that: 'Tous ces examples illustrent ce qui a déjà été dit dans la partie précédente de Bar Zu'bî sur les classes verbales, à savoir que le passif est formé par préfixation de 'et à la forme active', G. Bohas, 'Les accidents du verbe', p. 66. Unfortunately Bohas does not include in his article the section on verbal classes to which here reference is made, therefore it is not possible at the moment to analyse this information in more detail. 40) For a sketch of the history of Arabic linguistics cf. G. Bohas, J.P. Guillaume, and Dj.E. Kouloughli, The Arabic Linguistic Tradition (London and New York: Routledge, I990). 
to questions, subdivided into chapters. The author, nevertheless, was not able to abandon completely the method followed by previous Syriac tradition, so that the structure of his work appears a bit confused. ${ }^{41}$

In the introduction to his work Elias himself indicates in the Arabic grammar (grammatîi $\hat{\imath}$ arabî̀ayt) and in the Aristotelian logics (mlîltå d-bêt ariståatelîs) the sources for his research, but mixed together with previous Greek and Syriac grammatical tradition: 'I have put together various things from the Greek grammar - although I don't know Greek - and those traditions that are available about Syriac'.

In this grammar there is no explicit mention of diathesis, the way it has been defined in the Téchne and its imitators. Nevertheless, problems connected with it are discussed in various sections.

The question opening the first chapter is the following:

by means of which signs do we indicate the agent (' $b \hat{u} d \stackrel{a}{a})$ that is the performer ( $\left(\hat{a}^{\circ} \hat{u} r a ̊\right)$ in the Syriac language? The Arabic language has in fact in the grammatical terms signs for the one who effects and the one who undergoes, namely fá $i l$ and maf $\bar{u} l^{42}$

A long and detailed description follows, about which are the means of distinguishing the agent from the patient, ${ }^{43}$ and which are the possible patientmarkers. It is a completely different approach from the one we have seen so far, and it does not relate to diathesis stricto sensu, meant as a quality of the verb.

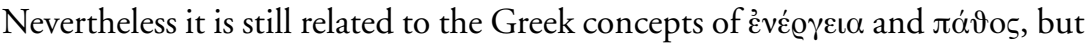
through the mediation of the Arabic linguistic and logic reflection.

In chapter three another interesting problem is addressed: how is it possible to recognize that a noun is a patient, when the agent is not openly expressed. It is a question that could also be addressed by modern scholars dealing with diathesis. From a modern perspective the problem regards the possibility of distinguishing between a real passive and a middle or a reflexive structure. On

41) A. Merx, 'Historia artis grammaticae', p. 155, remarks on this point: 'Sed voluntas laudabilior fuit quam id quod praestitit [...] ita ut opus imperfectum et confusum composuerit'.

42) F. Bäthgen, Syrische Grammatik des Mar Elias von Tirhan, (Leipzig: I880), p. 4*.

43) Elias identifies here three ways of distinguishing the Agent from the Patient: I. semantically 'First is the essence (yåtå) i.e. the natural possibility (mkånutå) of the agent and of the patient (met'abdana)'; 2. syntactically (or morphologically according to the Syriac point of view, that considers the prepositions as equivalents of the Greek case endings) 'Second by means of letters that are called articles (mašryåtå / šåryåtå), like $b-, d-, l$ Although properly we indicate the Patient with $l-$ '; 3. (again) syntactically 'Third from the order and the precedence of the nouns', F. Bäthgen, Syrische Grammatik, p. 4*. 
the contrary, Elias wants to explain how it is possible to recognize in Syriac that a certain noun is undergoing (and not performing) the action described by the verb. This problem has its roots in Arabic linguistic theory.

In Arabic, according to the grammarian, the distinction is made by means of different vowel patterns. In Syriac a specific vowel pattern is not needed, the forms with et-prefix convey the passive meaning:

Question: From which signs and marks is recognized a name that is patient (lit. faciendum) whose agent was not mentioned together with it?

Solution: We have remarked before that the nouns do not undergo any alteration [scil. Do not receive any case-marking], even when meanings are added; ${ }^{44}$ thus when we mention something effected by means of a verb meaning an action, we distinguish what is effected and that is enough, although we do not need a different vowel (scil. 'vocalization') of the noun, as in Arabic usage. For instance, when we say etmaḥhî nûh 'Noah was beaten', it is enough for us a transformation of the verb to indicate that Noah [is the object] of the wounds. Thus even when we speak about actions such as etkteb ktåbå 'The book/script was written' and esta'rat så 'ûrûtå 'the action was done' and etyahbat zkîtå 'the victory was given'. ${ }^{45}$

It is implicit in the examples given in this passage that the et-prefix is associated primarily with the expression of passivity and of an action undergone. It is interesting to notice that no reference is made to passive vocalization in Syriac, even though it is available for the passive participles of all stems. Also this circumstance could be explained in the light of Arabic categorizations.

\section{The Grammatical Dialogue of Bar Šakku and the Diathesis of Nouns}

Bar Šakku was contemporary and disciple of Bar Zu'bî (†' $24 \mathrm{I})$. He is the author of a compendium on the seven artes liberales (cf. Merx), ${ }^{46}$ the first part of which (edited by Merx) is devoted to grammatical issues. This work, like that of Elias of Tirhan, is structured as a series of questions and relative answers. Both Greek and Arabic influences can be found in the way in which the various topics are addressed.

In Bar Šakku we find explicit mention of diathesis, with an approach that shows both Greek and Arabic influence.

44) F. Bäthgen, Syrische Grammatik, p. I3: 'auch wenn sie in verschiedener Beziehung gebraucht werden'.

45) F. Bäthgen, Syrische Grammatik, p. 7*.

46) A. Merx, 'Historia artis grammaticae', p. 2 IO. 
In the first part of his treatise, the author lists the categories of affixes (nqîpan) of the various parts of speech, in line with the tradition of the Téchne:

third question: which are the affixes (attaching) to each one of the parts of speech?

answer: and we say that to the noun attach: genders (gensề), species (ådrè), schemes (eskimề), numbers (menyånê), diatheseis (lit. 'quality' aynåywåtå), cases (mappeltề). ${ }^{47}$

Diathesis is therefore introduced as a quality of the noun, as was already found in Huzaya's transaltion (and in the Téchne itself). Each of the categories is then explained in more detail. About diathesis it is said:

Diatheseis (aynåywåtå) are four:

I. active (ma'bdånutå), as when it is said qtûlå (murderer), ktûbå (writer, scribe), 'bûdå (maker), ktûbûtå (script/profession of copyist), qtûlûtå (murder);

2. passive (hăåă like for example 'bîdå (fact), ktîbå (writing), qtîlå (killed), 'bîdûtå (creation), qț̂̀lûtå (being slain), ktîbûtå (writing, script), met'bdånå (acted on), metkatbånå (written/litterate);

3. quality (qanåyûtå) ${ }^{48}$ as when you say: zaddîqå (righteous), 'awwålå (unrighteous), tåbå (good), bîša (evil) myatrå (excellent), malkå (king) zaddîqûtå (righteousness), 'awwalûtå (injustice), ḩûbå (love);

4. manifestation of nature (mhawyånûtå d-kyånå), as when you say, barnåša (man),

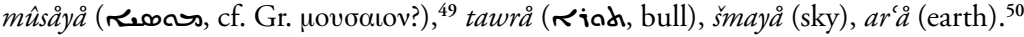

The third and fourth qualities seem to be mostly semantically based and they do not relate to diathesis. The first two qualities in stead are clearly connected to diathesis and are associated to precise morphological patterns. Under the active are listed so-called nomina agentis, ${ }^{51}$ and their respective derived abstract forms in - $\hat{u} t a ̊$. The passive, instead, is referred to the pattern $q t \hat{\imath} l$, the passive

\footnotetext{
47) A. Merx, 'Historia artis grammaticae', p. $3^{*}$.

48) This term means 'property, quality' and is related to the verb qnå 'to gain, obtain'.

49) Cf. L. Costaz, Dictionnaire Syriaque-Français = Syriac-English dictionary $=$ Qāmūs Siryāni-'Arabì (Beyrouth: Imprimerie Catholique, 1963), p. 178.

50) A. Merx, 'Historia artis grammaticae', pp. 3-4*.

51) A noun akin to the active participle, defined in T. Muraoka, Classical Syriac, $\$_{5 \mathrm{I}}$ as 'a noun denoting a person who executes the action indicated by the verb'. In the basic stem $p^{\prime} a l$ it has the pattern qtûl. In the derived stems, in stead, is done by adding -ana to the participle: this is the pattern of the forms met'bdana and metkatbana listed among the passives.
} 
participle of the basic stem $\left(p^{\prime} a l\right)$, and the corresponding derived in $-\hat{u} t \dot{a}$, but also to nomina agentis of et-derived stems. ${ }^{52}$

Problems related to diathesis are also treated in the questions II and I2. Question II closely resembles the one found in Elias of Tirhan and discussed above ( $\$ I I I$. and n. 43) ${ }^{53}$ Question I2 deals with the affixes that convey passivity.

\section{The final synthesis: diathesis in the Ktabå d-ṣemhêe of Bar Hebraeus}

Let us now consider another description of Syriac language, that is considered the apex of ancient Syriac linguistic reflection, for its completeness and its systematic structure.

It is the Ktaba $d$-sembê, composed by Bar Hebraeus in the XIII century, in which all the previous approaches to the Syriac language, diversely connected to the Greek Téchne, to the Syriac masoretic tradition and to the Arabic descriptive methods, are collected and harmonized.

Diathesis is treated explicitly by Bar Hebraeus, both as a feature of the noun and of the verb. Thus, in the chapter on the noun he lists it among the properties of the noun, following the Téchne in the organization of the matter, but also expressing the same content that was already found in Huzaya and Bar Šakku:

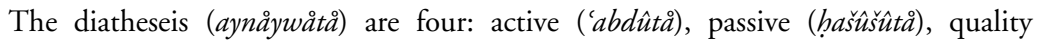
(qanåy $\hat{u}$ å) and demonstration of nature (mhawyånûtå d-kyånå). ${ }^{54}$

In spite of the analogy in the initial formulation, the way the various diatheseis are exemplified differs significantly from the one chosen by Bar Šakku. Bar Hebraeus says:

52) Diathesis as a property of the noun is found also in the grammar of Bar Hebraeus (cf. $\$ V$.). This subject will be discussed in depth in $\$ V$. and $V I$.

53) Q II-Through which marks do we recognize an agent from a patient? A—And we say from three signs: I. from the essence, that is the nature of the agent and of the patient; 2.

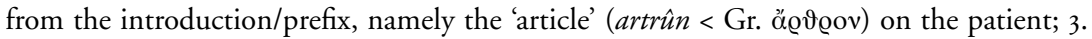
from the order and the precedence of the nouns; 4 . priority of the agent on the patient.

54) A. Moberg, Le livre des splendeurs. La grande grammaire de Grégoire Barhebraeus. Texte syriaqe édité d'après les manuscrits avec une introduction et des notes (Lund: Gleerup, 1922), p. 36. 
And the agent ('abuda) ${ }^{55}$ is the noun in front of which the verb, and what is like it, is [placed], as 'Paul preaches' (akrez pawlîs) and 'Paul, ${ }^{56}$ his disciple is an announcer' (pawlûs, msabrån talmîdeh). [...] And the patient (hášusåa) is the one on which falls the verbal action (melat så ûrûtå), like 'our Lord struck the Egyptians' (mhå måryå l-mezråyê) and 'he went to the land of the Gadarenes' (w-etå l-atrå d-gådråyê)..$^{57}$

Merx ${ }^{58}$ has brilliantly identified the direct source of this passage (as of many others in the grammar of Bar Hebraeus) in the Arabic grammar of Zamahšsarî (X-XI cent.) mufassal fí 'ilm al-'arabiyya. The definition of 'abûdå corresponds almost literally to the one of the Arabic fác $i l$.

In the section devoted to the verb we find again the ordinate structure used by Bar Zu'bî and Huzaya and derived from the Greek Téchne. Diathesis is explicitly mentioned and treated as one of the kinds of affixes, or accidents of the verb.

On the types of affixes of the verb.

The types of affixes of the verb are seven: I. the gender, masculine or feminine, like . כל

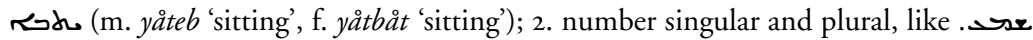

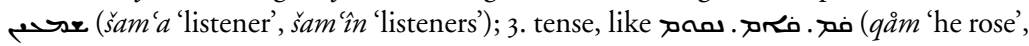

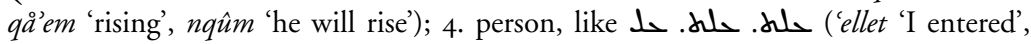

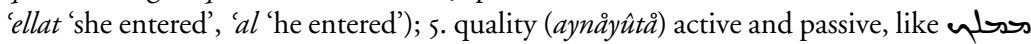
(mamlek 'being king') with rbåså ( $e$ vowel) låmad ( $l$-) among others, sك (mamlak 'being made king') with ptåḥa (a vowel) låmad, among others, Gospel (w-kad šma'd-arkelầs mamlek b-îhûd 'And when he heard that Archelaus had been made king of Judaea') i.e. by Cesar. 6. eskîm simple, composed and extra-composed, like, Iawudir , wodir ( ethzawzî 'he distinguished himself'); 7. disposition of the five species of the discourse, which the Holy [Bishop] (scil. Jakob of Edessa) called וis (zanåyê 'varieties'), and others مi مiryåtå 'invocations'), like command, request, question, exclamation, declaration. ${ }^{60}$

In the quoted passage, points 5. and 6. are particularly interesting for our analysis. Two diatheseis (aynåyûtå, quality) ${ }^{61}$ are here posed for the verb: active

55) Morphologically and semantically related to 'abdûtå, as explained also by Bar Šakku, cf. $\$ I V$.

56) Casus pendens.

57) A. Moberg, Le livre des splendeurs, p. 36.

58) A. Merx, 'Historia artis grammaticae', p. 24I.

59) Cf. Matt. 2.22.

60) A. Moberg, Le livre des splendeurs, p. 90.

61) From the root of interr. ayna 'what'. 
and passive (the terms used are built from the same roots used by Huzaya). No reference is made to a 'middle quality'. The opposition between active and

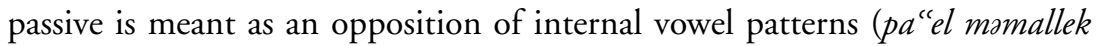
vs mamallak), ${ }^{62}$ no $e t$-form is used to illustrate the passive. Moreover, for the passive diathesis, a full sentence is given as an extra example. It is a Gospel quotation from Matt. 2.22 in which the form mamallak 'he was made king' is used. It is noteworthy that here Bar Hebraeus, in order to explain the 'passivity' of the sentence, specifies that an agent is implied: 'by Cesar' (men qesar).

After the definition of active and passive, in point 6. the forms (or stems) of the verbs are introduced. Here we find the $e t$ - forms, described as 'composed' and 'extra-composed', but from a purely morphological perspective, without any concern about the meaning. ${ }^{63}$

\section{Conclusions}

As regards middle diathesis, from this overview emerges that the only reference to it in ancient Syriac grammar is in Huzaya's translation of the Téchne. There it is indicated with the term mes'ayntå and is kept separate from the passive (represented by the et-stems) and exemplified with non-accusative motion verbs. This choice, together with the organization of the examples, with respect to their Greek equivalents, shows that the translator has consciously introduced 'middle' as a separate verbal category (even though on semantic grounds), and that he did not only operate a mechanical transposition of the Greek original.

Diathesis is indeed treated also in the later works, but always as a bipartite category, divided into active and passive. The way the two diatheseis are exemplified varies, but the passive is constantly connected with the $e t$ - prefix.

Particular attention deserves the so-called diathesis of nouns. This category, as was shown above, was already present in the Téchne, even though only as a quick reference, that has moreover been heavily criticized by the subsequent commentators. Nevertheless it had quite some success within ancient Syriac tradition.

Let us now consider the examples of the diatheseis of the noun given in the works analysed in this study.

62) Or afel mamlek vs mamlak.

63) The tripartite classification of verbs is once again derived from the Téchne, cf. G. Uhlig, Dionysii Thracis ars grammatica, pp. 50-51. 


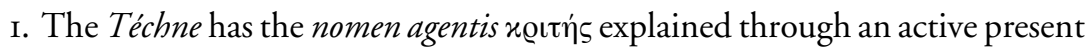

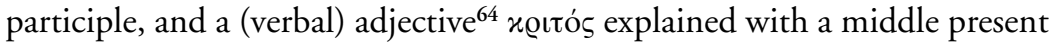
participle. The category of diathesis, therefore, even though it is not used as a verbal feature, refers here to two specific morphological classes of verbal nouns, and is connected with the correspondent participles. ${ }^{65}$ Unlike verbs, nouns do not have a middle diathesis.

2. Huzaya reproduces faithfully the Greek examples, giving for xœın's the semantically equivalent noun dayånå, also explained through an active participle, for x@ıtó the form mettdînånå, a noun derived from the etp'el participle through the suffix - an , according to a regular derivational process. It is explained with a etp'el participle.

3. Bar Šakku indicates for the two diatheseis of the noun two derivational patterns: the nomen agentis 'abûd for the active, the passive participle 'bîd and the nouns in -an, derived from the participles of et-stems, for the

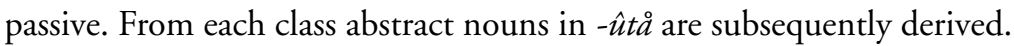

4. Bar Hebraeus chooses a completely different approach. He does not give lists of examples, variously connected with the Syriac derivational system. In stead, he first establishes a correspondence between 'abûdûtå (active

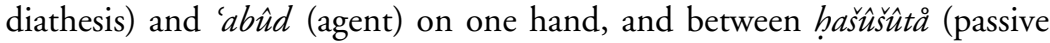
diathesis) and ḩašǔša (patient). After that, Bar Hebraeus gives two general definitions of agent and patient, syntactically and partly semantically based. The examples that follow each definition do not refer to a morphological category in particular, but to a sentence structure. As already mentioned $(\$ V$.$) , Merx { }^{66}$ has recognized in this passage of the Ktabå $d$-șembê the Syriac rendering of the definition of the $f \bar{a}$ i $i l$ فiven by the Arabic grammarian Zamahšarî. There the $f \bar{a}$ ' $i l$ 'agent' is individuated syntactically as al-musnadu ilayhi mina l-fil المسند اليه من الفعل 'the one preceded by the verb'.

This last concept, that in Bar Hebraeus is literally rendered as general definition of 'abùdå, is present also in some of the older Syriac grammars, but next to other different points of view (cf. the answer to the first question in the grammar of Elias of Tirhan, n. 43, and the answer to the IIth in Bar Šakku's grammar n. 53).

64) The nominal pattern in -to- interferes from an early stage with the verbal paradigm,

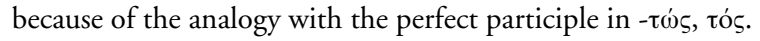

65) Cf. on this the remark of the Scholiast, in n. 28.

66) A. Merx, 'Historia artis grammaticae', p. 24I. 
Numerous different perspectives, variously combined by the single authors, contribute to the construction of the definition of diathesis in Syriac language given in antiquity. Under the influence of the Arabic syntactical theory of $f \bar{a} i l$ and maf $\bar{u} l$, the short reference to the diathesis of the noun in the Téchne, is broadly developed, without being explicitly connected to the diathesis of the verb. ${ }^{67}$ If the distinction between active and passive in the (verbal) nouns is mainly based on syntax, the diathesis of the verb remains a morphological feature, the presence of the et-prefix.

The Arabic point of view and terminology seem to be eventually predominant, but the previous tradition and elaboration is partly preserved as a coexisting stream, enriching and complicating the picture.

67) The Arabic theory of passive and reflexive, also because of the significantly different structure of the Arabic verbal system with respect to the Syriac one, has not been assimilated by the Syriac grammarians. 